\title{
Pengaruh Model Pembelajaran Probing-Prompting Terhadap Hasil Belajar Siswa
}

\author{
Eka Purnamansari ${ }^{1}$, M. Yunan, H.S. ${ }^{2}$
}

${ }^{1}$ Pendidikan Pancasila dan Kewarganegaraan, Universitas Muhammadiyah Mataram, purnamansari.eka16@gmail.com

${ }^{2}$ Pendidikan Pancasila dan Kewarganegaraan, Universitas Muhammadiyah Mataram, yunanhs13@gmail.com

\begin{tabular}{l} 
INFO ARTIKEL \\
Riwayat Artikel: \\
Diterima: $\quad$ 17-Agustus- \\
2018 \\
Disetujui: $17-S e p t e m b e r-$ \\
2018 \\
\hline
\end{tabular}

Kata Kunci:

Pengaruh

pembelajaran

probing-promting

hasil belajar

\begin{abstract}
ABSTRAK
Abstrak: Praktik mengajar guru masih pragmatik dan dogmatik serta belum mampu menciptakan suasana belajar menantang, sehingga kebanyakan siswa bosan dan kurang termotivasi/bersemangat untuk mengikuti pembelajaran. Tujuan penelitian untuk mengetahui apakah terdapat pengaruh yang positif dan signifikan model pembelajaran probing-prompting terhadap hasil belajar siswa. Metode penelitian menggunakan kuantitatif dengan pendekatan eksperimen dalam bentuk Pre Eksperimen dengan Desain Static Group Comparison, desain ini menggunakan dua kelas, dengan jumlah 64 siswa. Metode analisis data menggunakan Homogenitas data dengan menggunakan Uji F, Normalitas Data dengan menggunakan rumus Chi kuadrat, dan Uji hipotesis dengan menggunakan rumus t-test. Hasil penelitian menunjukkan bahwa perhitungan uji hipotesis dengan menggunaan rumus uji-tes, maka diperoleh $t_{\text {hitung }}$ sebesar 6,037 sedangkan nilai $t_{\text {tabel }}$ pada taraf signifikan $5 \%$ dengan $\mathrm{dk}=+-2=32+32-2=62$ diperoleh harga sebesar 1,669. Dengan ini, maka dapat dikatakan hipotesis $(\mathrm{Ha})$ diterima. Ini berarti bahwa "Terdapat pengaruh model pembelajaran probing-prompting terhadap hasil belajar PPKn kelas VII SMP Negeri 1 Sape". Sesuai dengan hasil penelitian yang dilakukan terdapat pengaruh yang signifikan model pembelajaran probing-ptompting terhadap hasil belajar PPKn kelas VII diperoleh 94,3\% pengaruh hasil belajar siswa setelah diterapkannya model pembelajaran probing-prompting di kelas VII SMP Negeri 1 Sape dan sisanya 5,7\% dipengaruhi oleh variabel lain.
\end{abstract}

\begin{abstract}
Teacher teaching practice is still pragmatic and dogmatic and has not been able to create a challenging learning atmosphere so that most students are bored and less motivated/eager to follow the learning. The research aims to determine if there is a positive and significant influence of probing-following prompting learning model towards student learning outcomes. The research method of using quantitative with the experimental approach in the form of Pre experiment with Static design Group Comparison, this design uses two classes, with the number of 64 students. Data analysis methods use data homogenization Using Test F, Data normality by using Chi-squared formula, and hypothesis test by using T-Test formula. The results showed that the calculation of the hypothesis test by using test-test formula then obtained Thitung amounted 6.037 while the value of a significant $5 \%$ with $D K=+-2=32+32-2=62$ obtained a price of 1.669 . With this, the hypothesis can be said ( $\mathrm{Ha}$ ) acceptable. This means that "there is the influence of probingfollowing prompting learning model to the results of the study of PPKn class VII SMP Negeri 1 Sape". In accordance with the results of research carried out there is a significant influence model learning probing-promoting to the outcome of PPKn class VII gained 94.3\% influence of student learning outcomes after the learning model Probing-following prompting in class VII SMP Negeri 1 Sape and the remaining $5.7 \%$ is influenced by other variables.
\end{abstract}

\section{A. LATAR BELAKANG}

Tujuan pendidikan nasional adalah perkembangannya potensi peserta didik agar menjadi manusia yang beriman dan bertaqwa kepada Tuhan Yang Maha Esa dan berakhlak mulia, maka garis-garis besar progam pengajaran sejarah memuat pokok-pokok bahasan yang mengandung tujuan Pendidikan Nasional tersebut. Sebagai sarana pendidikan, pengajaran sejarah sangat penting karena mempunyai fungsi pembentukan watak bangsa kiranya sudah sering diungkapkan dikalangan sejarawan maupun orang awam bahwa sejarah sangat penting artinya bagi pendidikan pada umumnya dan pendidikan karakter bangsa. Pendidikan Nasional adalah pendidikan yang berdasarkan Pancasila dan Undang-undang dasar Negara Republik Indonesia 1945 yang berakar pada nilai-nilai agama, kebudayaan nasional Indonesia dan tanggap terhadap tuntutan perubahan zaman[1]. Pembelajaran PPKn bukanlah semata-mata pelajaran yang hanya mengetahui keadaan warga negara saja, akan tetapi kita perlu tahu bahwa menerapkan sikap patriotisme dan nasionalisme harus tercermin pada diri siswa itu sendiri, sehingga mempelajari PPKn sangat penting bagi generasi muda, 
terutama pada siswa dan siswi yang duduk dibangku sekolah SD, SMP/MTs, SMA/MA dan perguruan tinggi.

Hasil belajar pada dasarnya merupakan tujuan belajar yang berhasil dicapai oleh siswa. Hasil belajar berguna untuk mengetehui sejauh mana penguasaan materi yang dipelajari. Hasil belajar dapat berupa angka, huruf maupun tindakan dan menghasilkan pola, pengertian, nilai, sikap dan keterampilan. Belajar aktifitas mental yang terjadi karena adanya interaksi aktif antara individu dengan lingkungannya yang menghasilkan perubahan-perubahan yang bersifat relativ tetap dalam aspek kognitif, psikomotor dan afektif. Perubahan tersebut dapat berubah sesuatu yang sama sekali baru atau penyempurnaan dari hasil belajar yang telah di peroleh sebelumnya.

Hasil observasi di sekolah SMP Negeri 1 Sape menunjukkan bahwa dalam proses pembelajaran PPKn di kelas, guru masih menerapkan model pembelajaran convensional yaitu guru memberikan pengenalan topik yang dibahas pada pertemuan hari itu. Dengan metode ini diterapkan untuk materi-materi yang berkaitan dengan keterampilan membaca, menulis, dan mendengarkan. Sehingga kegiatan belajar siswa hanya terpacu pada mebaca, menulis, dan mendengarkan saja. Kegiatan proses belajar mengajar lebih berpusat pada guru dan pada buku pegangan siswa sehingga komunikasi satu arah dari guru kepada siswa kurang. sedang siswa hanya membaca, menulis, dan mendengarkan apa yang disampaikan guru sehingga cenderung meminimalkan keterlibatan siswa serta guru nampak lebih aktif atau dan belum menerapkan model pembelajaran inovatif yang bersifat konstruktivis sesuai dengan paradigma. Guru masih menerapkan model pembelajaran konvensional yaitu memberi materi melalui ceramah, dapat dipahami bahwa hasil belajar siswa masih belum memenuhi standar ketuntasan dalam belajar[2]. Siswa kurang berminat pada mata pelajaran PKn karena guru tidak menerapkan model pembelajaran yang bervariasi namun mereka hanya selalu mengajar secara monoton satu konsep pembelajaran berupa ceramah sehingga berdampak pada prestasi siswa itu sendiri tidak meningkat[3].

Akibat dari kurang aktifnya siswa sehingga mengakibatkan rendahnya prestasi belajar siswa. Hal ini disebabkan karena pada saat proses belajar mengajar siswa jarang untuk menanyakan hal-hal yang belum paham tentang materi yang disampaikan. Bahkan banyak siswa yang terlihat malas dan tidak percaya diri untuk menjawab pertanyaan yang diberikan oleh guru. Hal ini terlihat dari data hasil ulangan akhir semester siswa sebelumnya, yakni dari 64 siswa hanya 25 (39,7\%) siswa yang mencapai kriteria ketuntasan minimal (KKM) siswa yang mendapatkan nilai 75 sebanyak 5 orang, 80 sebanyak 9 orang, 85 sebanyak 9 orang, dan yang mendapatkan nilai 90 sebanyak 2 orang. dan $39(60,9 \%)$ siswa belum mencapai nilai ketuntasan mininal (KKM) siswa yang mendapatkan nilai 50 sebanyak 8 orang, 60 sebanyak 10 orang, 65 sebanyak 10 orang, 70 sebanyak 11 orang yang telah ditetapkan oleh pihak sekolah yaitu 75, sehingga membuat sebagian besar siswa harus mengikuti program remedial untuk memperbaiki nilai.

Guru belum memaknai secara mendalam teori konstruktivis dalam merencanakan dan melaksanakan pembelajaran. Guru memandang bahwa dalam paradigma konstruktivis hanya siswa yang aktif tanpa ada intervensi guru atau keterlibatan guru sebagai mediator dan fasilitator bagi siswa. Selain itu, dalam praktik mengajar guru masih pragmatik (mendidik menggunakan pengalaman) dan dogmatik (hanya satu metode) serta belum mampu menciptakan suasana belajar yang menantang, sehingga kebanyakan siswa bosan dan kurang termotivasi dan semangat untuk mengikuti pembelajaran. Temuan lainya, yaitu sebagian besar pembelajaran berorientasi pada materi dan tidak pada kompetensi. Artinya pembelajaran yang dilakukan terlalu bergantung pada materi yang ada di buku.

Pemilihan model dan metode pembelajaran yang sesuai dengan tujuan kurikulum dan potensi peserta didik merupakan kemampuan dan keterampilan dasar yang harus dimiliki oleh seorang guru. Metode merupakan salah satu komponen dalam proses belajar mengajar yang berpengaruh terhadap pencapaian tujuan pembelajaran[4]. Hal ini didasari oleh asumsi bahwa ketepatan guru dalam memilih model dan metode pembelajaran akan berpengaruh terhadap motivasi, keberhasilan dan hasil belajar peserta didik, karena model dan metode pembelajaran yang digunakan oleh guru berpengaruh terhadap kualitas proses belajar mengajar yang dilakukannya.

Salah satu tantangan mendasar dalam pembelajaran PPKn dewasa ini adalah mencari model pembelajaran inovatif yang memungkinkan bagi peningkatan mutu PPKn. Hal ini dirasakan mendesak seiring dengan perkembangan dan kemajuan ilmu pengetahuan dan teknologi yang semakin pesat.

Perkembangan dan kemajuan ilmu pengetahuan dan teknologi tersebut, membuka kemungkinan peserta didik tidak hanya belajar didalam kelas yang dibimbing oleh guru, akan tetapi peserta didik dapat belajar dari luar kelas seperti dari lingkungan, masyarakat, pakar atau ilmuan, birokrat media cetak maupun elektronik serta sarana-sarana lain yang tesedia. Dengan belajar seperti itu peserta didik akan lebih leluasa menuangkan gagasan atau ide-idenya yang dibangun berdasarkan informasi dari berbagai sumber.

Sehubungan dengan hal tersebut, maka upaya peningkatan kualitas proses belajar mengajar dalam pendidikan PPKn merupakan suatu kebutuhan yang sangat mendesak untuk dilakukan. Salah satu model pembelajaran tersebut adalah Model Pembelajaran Probing-Prompting. Model pembelajaran ProbingPrompting adalah pembelajaran dengan cara guru menyajikan serangkaian pertanyaan yang sifatnya menuntun dan menggali sehingga terjadi proses berpikir 
yang mengaitkan pengetahuan setiap siswa dan pengalamannya dengan pengetahuan baru yang sedang dipelajari. Selanjutnya siswa mengkonstruksi konsepprinsip-aturan menjadi pengetahuan baru, dengan demikian pengetahuan baru tidak diberitahukan[5].

Dengan demikian tujuan penelitian ini untuk mengetahui pengaruh model pembelajaran probingprompting terhadap hasil belajar siswa

\section{B. METODE PENELITIAN}

1. Metode yang Digunakan

Metode yang digunakan dalam penelitian ini adalah penelitian kuantitatif. Penelitian kuantitatif yaitu penelitian yang menganalisis data penelitian dengan perhitungan statistik. Pendekatan eksperimen[6] adalah suatu penelitian yang digunakan untuk mencari pengaruh perlakuan (treatmen) tertentu terhadap yang lain dalam kondisi yang terkendalikan.

Penelitian ini menggunakan pendekatan eksperimen dalam bentuk Pre Eksperimen dengan Desain Static Group Comparison. Pendekatan kuantitatif adalah pendekatan penelitian yang menganalisis data penelitian dengan perhitungan statistik. Eksperimen adalah suatu cara untuk mencari hubungan sebab akibat (hubungan kausal) antara dua faktor yang sengaja ditimbulkan oleh peneliti dengan mengurangi atau menyisihkan faktorfaktor lain yang menggangu[7].

Pre Eeksperimen yaitu tidak atau sedikit saja adanya pengendalian variabel luar atau masih dipengaruhi oleh variabel luar. Artinya, hasil eksperimen merupakan variabel terikat dan bukan semata-mata dipengaruhi oleh variabel independen. Pada penelitian ini peneliti mengunakan desain Static Group Comparison, desain ini menggunakan dua kelas, satu kelas dijadikan sebagai kelas ekperimen dan satu kelas lagi dijadikan sebagai kelas kontrol. Adapun desain penelitin ini digambarkan sebagai berikut:

Tabel 1

Desain Eksperimen Dalam Bentuk Pre Eksperimen Dengan Desain Static Group Comparison.

\begin{tabular}{ccc}
\hline Kelompok & Perlakuan & Pasca Test \\
\hline E (Eksperimen) & $\mathrm{X}$ & $\mathrm{Y}$ \\
K (Kontrol) & - & $\mathrm{Y}$ \\
\hline
\end{tabular}

2. Metode Penentuan Populasi dan Sampel

a. Populasi

Populasi adalah kelompok yang menjadi perhatian peneliti, kelompok yang berkaitan untuk siapa generalisasi hasil penelitian berlaku[8]. Apabila seseorang ingin meneliti semua yang ada dalam wilayah penelitian, maka penelitinya merupakan penelitian populasi. Populasi merupakan wilayah generalisasi yang terdiri atas subyek yang mempunyai kualitas dan karakteristik tertentu yang ditetapkan oleh peneliti untuk di pelajari dan kemudian ditarik kesimpulnya. Jadi populasi bukan hanya orang, tetapi juga bisa organisasi, hasil karya manusia, dan benda-benda alam lainnya.

Dalam penelitian ini populasi terdiri dari seluruh Siswa Kelas VII di SMP Negeri 1 Sape Tahun Pelajaran 2017-2018 yang berjumlah 288 siswa. Jumlah tersebut tersebar di 9 (sembilan) kelas dengan rincian masingmasing kelas, sebagaimana dapat dilihat pada tabel berikut :

Tabel 2

Data siswa Kelas di SMP Negeri 1 Sape Tahun Pelajaran 2017-2018

\begin{tabular}{cccc}
\hline \multirow{2}{*}{ Kelas } & \multicolumn{2}{c}{ Jenis kelamin } & \multirow{2}{*}{ Jumlah } \\
& Laki-laki & Perempuan & \\
\hline VII $^{1}$ & 10 & 22 & 32 \\
VII $^{2}$ & 15 & 17 & 32 \\
VII $^{3}$ & 15 & 16 & 31 \\
VII $^{4}$ & 23 & 9 & 30 \\
VII $^{5}$ & 19 & 14 & 33 \\
VII $^{6}$ & 18 & 13 & 31 \\
VII $^{7}$ & 16 & 17 & 33 \\
VII $^{8}$ & 18 & 12 & 32 \\
VII & 20 & 14 & 34 \\
Jumlah & 154 & 134 & 288 \\
\hline
\end{tabular}

\section{b. Sampel}

Sampel merupakan bagian penelitian populasi penelitian yang digunakan untuk memperkirakan hasil dari suatu penelitian[9]. Sampel adalah bagian dari jumlah karakteristik yang dimiliki oleh populasi. Sampel merupakan sebagian dari populsi yang dipilih oleh peneliti sebagai wakil dari populasi yang representatif yang dijadikan subyek dalam penelitian untuk memudahkan peneliti untuk mendapatkan dan mengumpulkan data di lokasi penelitian[10].

Dengan mempertimbangkan hal-hal diatas dan melihat keadaan populasi berkelompok-kelompok yaitu kelas VII1, maka dalam penelitian ini peneliti menggunakan sampel untuk memperoleh data penelitian. Adapun teknik yang digunakan dalam penelitian ini adalahh teknik simple random sampling yaitu teknik pengambilan sampel secara acak sederhana dengan menggunakan undian atau tabel angka random. Tabel angka random merupakan tabel yang dibuat dalam komputer yang berisi angka-angka yang terdiri dari kolom dan baris, dan cara pemilihannya dilakukan secara bebas. Pengambilan acak sederhana ini dapat menggunakan prinsip pengembalian sampel dengan pengembalian ataupun pengambilan sampel tanpa pengembalian.

Populasi berjumlah 288 yang tersebar di 9 kelas peneliti menetapkan kelas VII1 sebagai kelas eksperimen dan kelas VII2 sebagai kelas kontrol dengan jumlah keseluruhan 64 siswa. Cara demikian dilakukan bila anggota populasi dianggap homogen. Kelas VII1 dan kelas VII2 dipilih sebagai sampel karena dianggap homogen.

3. Metode Pengumpulan Data 
Metode pengumpulan data merupakan teknik atau cara yang dilakukan untuk mengumpulkan data. Metode menunjuk suatu cara sehingga dapat diperlihatkan penggunaannya melalui dokumentasi dan tes.

Adapun jenis-jenis metode penelitian yang digunakan dalam penelitian ini adalah :

\section{Dokumentasi}

Dokumentasi adalah teknik pengumpulan data yang dilakukan dengan cara melalui berbagai dokumentasi yang ada dan diperlukan oleh peneliti, seperti nilai yang ada pada leger guru, raport, dll[11]. Dokumentasi adalah teknik pengumpulan data yang tidak langsung ditujukan pada subjek penelitian, tetapi melalui dokumen[12].

\section{Wawancara}

Wawancara adalah teknik pengumpulan data dengan mengajukan pertanyaan kepada responden dan mencatat atau merekam jawaban-jawaban responden[12]. peneliti melakukan wawancara terhadap responden (siswa).

\section{Test}

Tes adalah serentetan pertanyaan atau latihan serta alat lain yang digunakan untuk mengukur keterampilan, pengetahuan, inteligensi, kemampuan atau bakat yang dimiliki oleh individu atau kelompok[13]. Tes adalah rangkaian pertanyaan atau alat lain yang digunakan untuk mengukur keterampilan, pengetahuan, inteligensi, kemampuan, atau bakat yang dimiliki oleh individu atau kelompok[12]. Untuk memperoleh data seperti yang dimaksud, maka teknik atau metode yang akan digunakan dalam penelitian ini adalah metode tes, yakni tes awal (Pretest) dan tes akhir (Posttest). peneliti memberikan tes kepada siswa.

\section{Instrumen Peneitian}

Instrumen penelitian adalah alat untuk fasilitas yang digunakan oleh peneliti dalam mengumpulkan data agar pekerjaan lebih muda dan hasilnya lebih baik,dalam arti lebih cermat, lengkap, dan sistematis, sehingga lebih muda diolah[12]. Suatu penelitian yang layak digunakan sebagai alat ukur, apabila telah dilakukan uji validitas dan uji realibilitas[13].

\section{a. Validitas}

Sebuah tes dikatakan memiliki validitas jika hasilnya sesuai dengan kriterium, dalam arti memiliki kesejajaran antara hasil tes tersebut dengan kriterium. Untuk mencari validitas butir soal dapat dicari dengan menggunakan rumus korelasi product moment sebagai berikut[13].

$$
r_{x y}=\frac{N \cdot \sum X Y-\left(\sum X\right) \cdot\left(\sum Y\right)}{\sqrt{\left.\left(N \cdot \sum X^{2}\right)-\left(\sum X\right)^{2}\right\}\left\{\left(N \cdot \sum Y^{2}\right)-\left(\sum Y\right)^{2}\right\}}}
$$

Keterangan:

$\mathrm{r}_{\mathrm{xy}} \quad=$ koefisien korelasi antar variabel $\mathrm{X}$ dan variabel $\mathrm{Y}$

$\mathrm{N}=$ jumlah siswa

$\Sigma \mathrm{X}=$ jumlah nilai variabel $\mathrm{X}$

$\Sigma \mathrm{Y}=$ jumlah nilai variabel $\mathrm{Y}$

$\Sigma \mathrm{XY}=$ jumlah nilai perkalian variabel $\mathrm{X}$ dan $\mathrm{Y}$
$(\Sigma X)^{2}=$ jumlah nilai variabel $\mathrm{X}$ dikuadratkan

$(\Sigma \mathrm{Y})^{2}=$ jumlah nilai variabel $\mathrm{Y}$ dikuadratkan

$\Sigma \mathrm{X}^{2}=$ jumlah kuadrat nilai variabel $\mathrm{X}$

$\Sigma \mathrm{Y}^{2}=$ jumlah kuadrat nilai variabel $\mathrm{Y}$

Nilai rxy akan dikonsultasikan dengan tabel $\mathrm{r}$ product moment kriteria pengujian yaitu:

- $\quad$ jika rxy $\geqslant$ rtabel maka soal dikatakan valid

- jika rxy< rtabel maka soal dikatakan tidak valid

Setelah diperoleh nilai kemudian dicocokkan dengan tabel $r$ product moment.

Sesuai hasil analisis uji validitas butir soal diujicobakan, yang terdiri dari 25 butir soal, dimana pengujiannya dilakukan dengan membandingkan tiap butir soal. Nilai yang digunakan adalah niali $r$ pada taraf signifikan $5 \%$ untuk $\mathrm{N}=32$ yaitu 0,361 dengan kriteria valid suatu butir soal bila, dari 25 soal yang diujikan terdapat 20 soal yang valid dan 5 soal yang tidak valid.

\section{b. Reliabilitas}

Reliabilitas adalah suatu alat pengukur dikatakan reliable bila alat itu dalam mengukur suatu gejala pada waktu yang berlainan senantiasa menunjukkan hasil yang sama[14]. Dalam uji reliabilitas berupa tes digunakan Kuder Richardson 20 (KR-20).

Adapun rumus KR-20 sebagai berikut:

$r_{11}=\left(\frac{n}{n-1}\right)\left(\frac{s^{2}-\sum p q}{s^{2}}\right)$

Dimana:

$\mathrm{r}_{1}=$ reliabilitas tes secara keseluruhan

$\mathrm{p}=$ proporsi subjek yang menjawab item dengan benar

$\mathrm{q}=$ proporsi subjek yang menjawab item dengan salah (q $=1 \mathrm{p})$

$\sum p q=$ jumlah hasil perkalian antara $\mathrm{p}$ dan $\mathrm{q}$

$\mathrm{n}$ = banyaknya item

$\mathrm{s}=$ standar deviasi dari tes ( standar deviasi adalah akar varians)

Sedangkan di buku-buku lain n (n kecil) ini sering diganti dengan huruf $\mathrm{k}$ (k kecil), yang juga melambangkan banyaknya item. Demikian juga huruf $\mathrm{S}$ sebagai lambing standar deviasi, dituliskan SB sebagai singkatan dari kata "Simpangan Baku." Maka rumus KR20 menjadi :

$$
\mathrm{r}_{11}=\left(\frac{k}{k-1}\right)\left(\frac{S B^{2}-\sum s ; q}{S B^{2}}\right)[13]
$$

$$
\begin{aligned}
& \text { Hitungan realibilitas } \\
& \mathrm{K}=25 \\
& \mathrm{k}=25-1=24 \\
& \mathrm{SB}=399,374 \\
& \sum p q=6,02222 \\
& \text { Ditanya } r_{11} \ldots ? \\
& \text { Jawab: } \\
& \mathrm{r}_{11}=\left(\frac{k}{k-1}\right)\left(\frac{5 B^{2}-\sum \nabla_{4}}{\$ B^{2}}\right) \\
& \mathrm{r}_{11}=\left(\frac{25}{25-1}\right)\left(\frac{399,374-6,02222}{999,974}\right)
\end{aligned}
$$




$$
\begin{aligned}
& \mathrm{r}_{11}=\left(\frac{25}{24}\right)\left(\frac{399,374-6,02222}{399,374}\right) \\
& \mathrm{r}_{11}=(1,04167)\left(\frac{393,351}{399,374}\right) \\
& \mathrm{r}_{11}=(1,04167)(0,98492) \\
& \mathrm{r}_{11}=1,02596
\end{aligned}
$$

Hasil uji reabilitas dimana soal yang diuji validitas dari ke 25 soal, dan hanya 20 yang valid yaitu nomor soal $1,2,3,4,5,6,7,8,9,10,11,12,13,14,15,16,17,18$, $19,20,21,22,23,24,25$, sehingga dalam perhitungan uji reabilitas yang valid saja dihitung, dan yang tidak valid tidak ikut disertakan dalam perhitungan uji reabilitas yaitu nomor soal 1, 2, 3, 4, 5, 7, 8, 9, 10, 12, 13, 14, 15, 16, $18,20,21,22,24,25$, dengan demikian hasil dari perhitungan uji reabilitas menggunakan rumus Richardson 20 (KR-20) dengan membandingkan mhitung $=1,02596$ sedangkan $r_{\text {tabel }}=0,361$ dengan demikian maka soal instrumen dapat disimpulkan realibel, karena Thitung $>r_{\text {tabel }}{ }^{x}$

\section{Jenis dan Sumber Data}

Jenis data yang dipergunakan dalam penelitian ini adalah jenis data kuantitatif. Jenis data kuantitatif yaitu data yang berjenis interval. Data kuantitatif dapat dibagi dua yaitu data variabel deskrit disebut data diskrit, berupa frekuensi, dan data dari variabel kuantum disebut data kuantum berupa ordinal, interval dan rasio[13].

Jenis data kuantitatif dapat dibedakan menjadi 4 yaitu:

1) Skala nominal, yaitu skala yang paling sedehana disusun menurut jenis (kategorinya) atau fungsi bilangan hanya sebagai simbol untuk membedakan sebuah karakteristik dengan karakteristik lainnya.

2) Skala ordinal ialah skala yang didasarkan pada ranking, diurutkan dari jenjang yang lebih tinggi sampai jenjang terendah atau sebaliknya

3) Skala interval adalah skala yang menunjukkan jarak antara satu data dengan data yang lain dan mempunyai bobot yang sama.

4) Skala ratio adalah skala pengukuran yang mempunyai nilai nol mutlak dan mempunyai jarak yang sama[15].

Data yang digunakan dalam penelitian ini berupa data kuntitatif yang berskala interval dan diperoleh dari hasil tes.

\section{Identifikasi dan Definisi Operasional Variabel \\ a. Identifikasi Variabel}

Variabel adalah suatu sifat atau nilai dari orang, subyek atau kegiatan yang mempunyai variasi tertentu yang ditetapkan oleh peneliti. Sugiyono, 2013. Variabel dibedakan menjadi dua yaitu variabel bebas dan variabel terikat, yang dimaksud dengan variabel bebas adalah variabel yang mempengaruhi atau yang menjadi sebab perubahannya atau timbulnya variabel dependen (terikat), sedangkan variabel terikat merupakan variabel yang dipengaruhi atau yang menjadi akibat, karena adanya variabel bebas[16].

Variabel bebas (independent variabel) yaitu model pembelajaran Probing-Prompting sebagai variabel yang mempengaruhi. Variabel terikat (dependen variabel) yaitu hasil belajar sebagai variabel yang dipengaruhi.

b. Definisi Operasional Variabel

Menurut kidder menyatakan bahwa variabel adalah suatu kualitas dimana peneliti mempelajari dan menarik kesimpulan darinya[16].

Berdasarkan pendapat diatas, definisi operasional variabel dalam penelitian ini adalah sebagai berikut :

1) Model pembelajaran ini menutut dan mengarahkan kemampuan berpikir siswa untuk mengkonstruksi pengetahuannya sendiri. Semua siswa dilibatkan dalam pertanyaan yang diberikan oleh guru secara acak, sehingga seluruh siswa tidak bisa menghindar dari proses pembelajaran. Pembelajaran dengan model ini mengikuti perkembangan kemampuan yang dimiliki siswa, sehingga proses pembelajaran dapat lebih efektif dan efisien.

2) Hasil belajar adalah suatu nilai yang merupakan cerminan dari hasil belajar, dimana nilai di sini sangat penting sebagai tolak ukur atau patokan terhadap gkeberhasilan siswa pada setiap bidang yang akan diajarkan di sekolah.

7. Metode Analisis Data

a. Uji Prasyarat Analisis

Sebelum dilakukan pengujian hipotesis maka terlebih dahulu dilakukan uji prasyarat analisis berupa uji homogenitas untuk mengetahui apakah varian kedua sampel tersebut homogeny atau tidak.

\section{b. Uji Homogenitas}

Uji homogenitas dipergunakan untuk membuktikan apakah dua sampel yang menjadi objek penelitian homogen atau tidak. Uji homogenitas ini dilakukan sebelum pemberian perlakuan. Uji homogenitas dilakukan dengan menggunakan uji F:[6]

$\mathrm{F}_{\text {hitung }}=\frac{\text { varians terbesar }}{\text { varians terkecil }}$

Dengan kriteria pengujian sebagai berikut data homogen jika $F_{\text {hitung }} \leq F_{\text {tabel }}$ dan data tidak homogen jika $F_{\text {hitung }}>$ $F_{\text {tabel. }}$

c. Normalitas Data

Uji normalitas data dilakukan untuk mengetahui apakah data tes terdistribusi normal atau tidak. Uji normalitas dicari dengan menggunakan rumus chi kuadrat (Riduwan, 2014)

$$
\chi^{2}=\sum_{i=k}^{k} \frac{\left(f_{0}-f e\right)^{2}}{f_{e}}
$$

Keterangan:

$f_{o} \quad=$ Frekuensi yang diobservasi

$f_{e} \quad=$ Frekuensi yang diharapkan

$f_{o^{-}} f_{e}=$ Selisih data $f_{o}$ dan $f_{h}$ 
Suatu data akan terdistribusi normal jika $\chi^{2}$ hitung $\leq \chi^{2}$ tabel dan tidak terdistribusi normal jika $\chi^{2}$ hitung $>\chi^{2}$ tabel pada taraf signifikan $5 \%$ dengan derajat kebebasan $\mathrm{Dk}=\mathrm{k}-3$ dimana $\mathrm{k}$ menyatakan jumlah kelas interval.

\section{d. Uji hipotesis}

Uji- $t$ untuk menghitung pengaruh pengajaran menggunakan model pembelajarn probing-prompting terhadap hasil belajar PKn pada siswa dilakukan uji- $t$ dengan rumus:

$$
\begin{aligned}
& \text { Polled varians } \\
& \mathrm{T}=\frac{x 1-x^{2}}{\sqrt{\frac{(n 1-1) 1^{2}+(n 1-1) \sqrt{2}}{n 1+n 2-2}\left(\frac{1}{n 1}+\frac{1}{n 2}\right)}}[16]
\end{aligned}
$$

Keterangan:

$\mathrm{t}=$ nilai $\mathrm{t}$ yang dihitung

$\mathrm{x} \quad=$ nilai rata-rata kelas eksperimen

$\mathrm{x}_{2} \quad=$ nilai rata-rata kelas kontrol

$\mathrm{S}_{1}{ }^{2} \quad=$ varians kelas eksperimen

$\mathrm{S}_{1}{ }^{2} \quad$ varians kelas kontrol

$\mathrm{n}_{1} \quad=$ jumlas siswa kelas eksperimen

$\mathrm{n}_{2} \quad=$ jumlah siswa kelas kontrol

Dengan ketentuan jika $t_{\text {hitung }}>t_{\text {tabel }}$ maka hipotesis Ha diterima dan Ho ditolak jika $t_{\text {hitumg }}<t_{\text {tabel }}$ maka hipotesis nol (Ho) diterima dan Ha ditolak[11].

\section{HASIL DAN PEMBAHASAN}

\section{Deskripsi Data Hasil Penelitian}

Untuk mendeskripsikan hasil penelitian ini, langkah awal yang dilakukan oleh peneliti adalah untuk mengukur hasil belajar awal (Pre-test) siswa dengan menggunakan model pembelajaran konvensional kemudian diberikan perlakuan dalam jangka waktu tertentu dengan menggunakan model pembelajaran probing-prompting untuk mendapatkan hasil belajar akhir (post-test) siswa.

Penelitian ini yang akan dibahas adalah data tentang hasil belajar siswa yang menggunakan model pembelajaran probing-promptingdengan data kuantitatif yang bersifat angka-angka yaitu dengan melalui dokumenter yang dicatat melalui hasil tes belajar siswa dengan menggunakan model pembelajaran probingprompting.

Data mengenai hasil belajar siswa kelas kontrol dapat dilihat pada tabel berikut :

\section{Grafik 1}

Hasil Belajar Siswa Kelas Kontrol $\left(\mathrm{VII}^{2}\right)$ SMPN Sape Tahun Pelajaran 2017-2018.

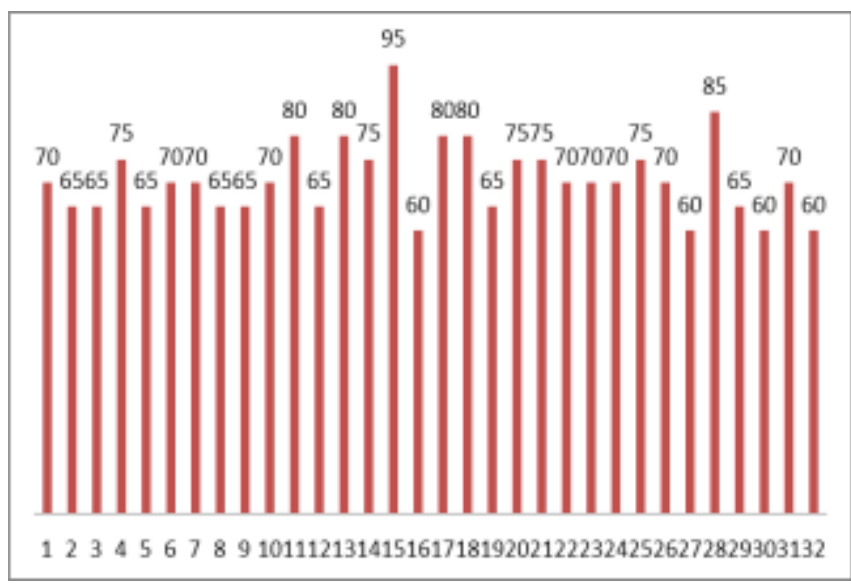

Sementara nilai rata mencapai:

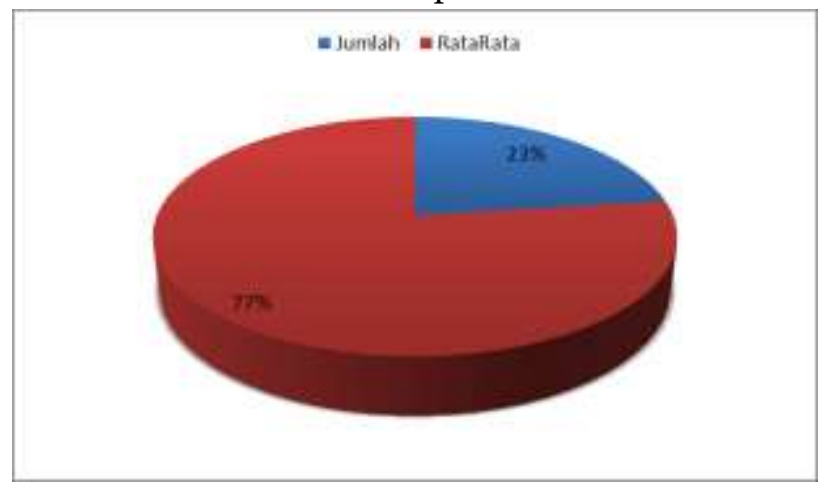

Grafik 1 di atas menunjukkan bahwa siswa yang tuntas sebanyak 11 orang, yang belum tuntas sebanyak 21 orang dengan nilai rata-rata 71,16 . Nilai tertinggi yang dicapai siswa adalah 95 sedangkan nilai terendahnya adalah 60.

Grafik 2

Hasil Belajar Siswa Kelas eksperimen (VII ${ }^{1}$ ) SMPN Sape Tahun Pelajaran 2017-2018.

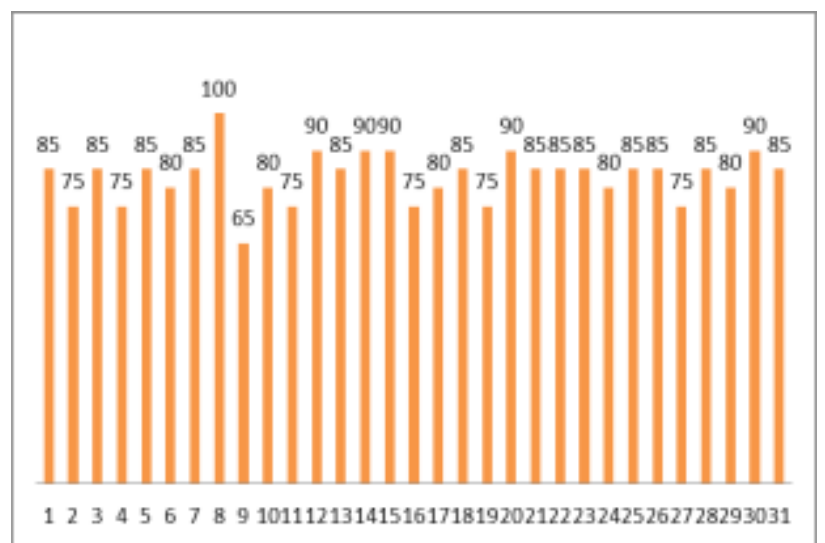

Sementara nilai rata mencapai:

G Jumkah Gitallata

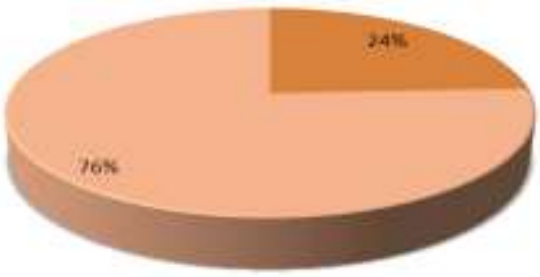


Grafik 2 di atas menunjukkan bahwa siswa yang tuntas sebanyak 310rang, yang belum tuntas sebanyak 1 orang dengan rata-rata 82,65 . Nilai tertinggi yang dicapai siswa adalah 100 sedangkan nilai terendahnya adalah 65.

\section{Tabel 3}

Deskripsi Data Hasil Belajar Siswa Kontrol dan Kelas Eksperimen

\begin{tabular}{lcc}
\hline Deskripsi & $\begin{array}{c}\text { Kelas Kontrol } \\
\left(\mathrm{VII}^{2}\right) \mathbf{N}=\mathbf{3 2}^{2}\end{array}$ & $\left.\begin{array}{c}\text { Kelas } \\
\text { Eksperimen } \\
(\mathrm{VII}\end{array}{ }^{1}\right) \mathbf{N}=\mathbf{3 2}$ \\
\hline Rata-rata & 71,16 & 82,65 \\
Skor maksimum & 95 & 100 \\
Skor minimum & 60 & 65 \\
\hline
\end{tabular}

Hasil belajar nilai rata-rata kelas kontrol yaitu 71,16 dan untuk skor maksimum 95 dan skor minimum 60, untuk kelas eksperimen hasil belajar nilai rata-rata 82,65 dan untuk skor maksimum 100, skor minimum 65.

\section{Analisis Data}

a. Uji Normalitas

1) Kelas Kontrol

Sebelum dilakukan uji hipotesis terlebih dahulu dilakukan uji normalitas. Untuk menentukan statistik apa yang harus digunakan dalam pengujian hipotesis. Uji normalitas data hasil belajar siswa kelas kontrol dilakukan dengan cara membandingkan hasil $\mathrm{x}^{2}$ hitung $<$ $\mathrm{X}^{2}$ tabel pada taraf signifikan $5 \%$. Hasil dari pengujian data setelah penggunaan model pembelajaran konvensioanal.

1. Menentukan skor tertinggi dan terendah

Diketahui : skor tertinggi $=95$

: skor terendah $=60$

$: \mathrm{N}=$ (jumlah siswa)

2. Menentukan rentangan (R)

$\mathrm{R}=$ skor tertinggi-skor terendah

$$
=95-60
$$$$
=35
$$

3. Menentukan Banyak Kelas (BK)

$$
\begin{aligned}
\mathrm{BK} & =1+3,3 \log \mathrm{n} \\
& =1+3,3 \log 32 \\
& =1+3,3(150) \\
& =6,45
\end{aligned}
$$

4. Menentukan Panjang Kelas (i)

$$
\mathrm{i}=\frac{R}{B K}=\frac{35}{6}=5,83=6
$$

Tabel 4

Distribudi Frekuensi Kelas Kontrol

\begin{tabular}{ccccccc}
\hline No & $\begin{array}{c}\text { Inter } \\
\text { val }\end{array}$ & $\boldsymbol{f}$ & $\mathbf{X i}$ & $(X i)^{2}$ & $\mathbf{f . X i}$ & $\mathbf{f .}(X i)^{2}$ \\
\hline 1 & $60-65$ & 12 & 62,5 & 3906,25 & 750 & 76875 \\
2 & $66-71$ & 9 & 68,5 & 4692,25 & 6165 & 42230,2 \\
& & & & & & 5 \\
3 & $72-77$ & 5 & 74,5 & 5550,25 & 3725 & 27751,25 \\
4 & $78-83$ & 4 & 80,5 & 6480,25 & 322 & 25921 \\
5 & $84-89$ & 1 & 86,5 & 7482,25 & 86,5 & 7482,25 \\
& Jumlah & 32 & & & 2240 & 158816 \\
\hline
\end{tabular}

Sumber Data : Data Hasil Penelitian Diolah
Batas kelas di peroleh dengan kelas interval bawah dikurangi 0,5 dan kelas atas ditambah 0,5 . Dari kelas interval didapatkan batas interval 59,$5 ; 65,5 ; 71,5 ; 77,5$; 83,$5 ; 89,5 ; 95,5$.

5. Menentukan Rata-rata atau Mean $(\bar{x})$

$$
\bar{X}=\frac{\sum f x i}{n}=\frac{2240}{32}=70
$$

6. Mencari simpangan baku (Standar deviasi)

$$
\begin{aligned}
& S=\sqrt{\frac{n \sum f x i-\left(\sum f x i\right)^{2}}{n-(n-1)}} \\
& =\sqrt{\frac{32(158916)-(2240)^{2}}{32 \cdot([22-1)}} \\
& =\sqrt{\frac{5097112-5017_{\Perp} 600}{992}} \\
& =\sqrt{\frac{64512}{992}} \\
& =65,0=8.06 \\
& \text { Nilai Z - Skor } \\
& \mathrm{Z}=\frac{\text { bataskelas-mean }}{\mathrm{s}} \\
& Z_{1}=\frac{59.5-70}{8.06}=-130 \\
& Z_{2}=\frac{65,5-70}{8,06}=-0,55 \\
& Z_{\mathrm{a}}=\frac{71,5-70}{8,06}=0,18 \\
& Z_{4}=\frac{77,5-70}{806}=0,93 \\
& Z_{5}=\frac{93,5-70}{8.06}=1,67 \\
& Z_{6}=\frac{99,5-70}{8,06}=2,41 \\
& Z_{7}=\frac{95,5-70}{8,06}=3,16
\end{aligned}
$$

Sehingga didapatkan masing-masing Z-Skor

Tabel 5

Mencari Nilai Z-Skor Kelas Kontrol

\begin{tabular}{ccccc}
\hline No & $\begin{array}{c}\text { Batas } \\
\text { Kelas }\end{array}$ & $\begin{array}{c}\text { Mean } \\
\text { (Rata- } \\
\text { rata) }\end{array}$ & $\begin{array}{c}\text { Standar } \\
\text { Deviasi }\end{array}$ & $\begin{array}{c}\text { Z- } \\
\text { Score }\end{array}$ \\
\hline 1 & 59,5 & 70 & 8,06 & -1.30 \\
2 & 65,5 & 70 & 8,06 & $-0,55$ \\
3 & 71,5 & 70 & 8,06 & 0,18 \\
4 & 77,5 & 70 & 8,06 & 0.93 \\
5 & 83,5 & 70 & 8,06 & 1,67 \\
6 & 89,5 & 70 & 8,06 & 2,41 \\
\hline
\end{tabular}

\section{Sumber data : Data Hasil Penelitian Diolah}

Mencari luas Z-skor dari tabel kurva normal dari O-Z dengan menggunakan angka-angka untuk batas kelas sehingga diperoleh : 0,4032; 0,2088; 0,0714; 0,3238; o,4525; o, 4920; o, 4992.

7. Luas kelas interval dengan cara mengurangkan angka-angka O-Z yaitu baris pertama di kurangi baris kedua, angka baris kedua di kurangi baris ketiga seterusnya.

$$
\begin{aligned}
& 30,4032-0,2088=0,1944 \\
& 40,2088-0,0714=0,1374 \\
& 50,0714-0,3238=-0,2524
\end{aligned}
$$




$$
\begin{aligned}
& 60,3238-0,4525=-1287 \\
& 70,4525-0,4920=-0,0395 \\
& 80,4920-0,4992=-0,0072
\end{aligned}
$$

8. Mencari frekuensi yang diharapkan (fe) dengan cara mengalikan luas interval dengan jumlah responden ( $n=32$ ), sehingga didapat sebagai berikut :

$90,1944 \times 32=6,2208$

$$
\begin{array}{ll}
10 & 0,1374 \times 32=4,3968 \\
11 & 0,2524 \times 32=0,0768 \\
12 & 0,1287 \times 32=4,1184 \\
13 & 0,0395 \times 32=1,264 \\
14 & 0,0072 \times 32=0,2304
\end{array}
$$

Dengan menggunakan

Rumus

$x^{2}=\sum_{i=1}^{k} \frac{(f o-f e)^{2}}{f e}$ dari tabel nilai $\chi^{2}$ hitung diperoleh 5,306, sedangkan $\chi^{2}$ tabel pada taraf kesalahan $5 \%$ dengan $\mathrm{dk}=\mathrm{k}-1=6-1=5$ yaitu 11,07, jika Jika $\chi^{2}$ hitung $>\chi^{2}$ tabel, maka data tidak terdistribusi normal, sedangkan jika $\chi^{2}$ hitung $<\chi^{2}$ tabel, makadata terdistribusi normal. Dari hasil perhitungan ternyata $\chi^{2}$ hitung $<\chi^{2}$ table yaitu $5,306<11,07$. Ini berarti data terdistribusi normal.

2) Kelas Eksperimen

Sebelum dilakukan uji hipotesis terlebih dahulu dilakukan uji normalitas. Untuk menentukan statistik apa yang harus digunakan dalam pengujian hipotesis. Uji normalitas data hasil belajar siswa kelas eksperimen dilakukan dengan cara membandingkan hasil $\mathrm{X}^{2}$ hitung $<$ $\mathrm{x}^{2}$ tabel pada taraf signifikan $5 \%$. Hasil dari pengujian data setelah penggunaan model pembelajaran probingprompting.

1. Menentukan skor tertinggi dan terendah

Diketahui : skor tertinggi $=100$

$$
\begin{aligned}
& : \text { skor terendah }=65 \\
& : \mathrm{N}=(\text { jumlah siswa) }
\end{aligned}
$$

2. Menentukan rentangan (R)

$\mathrm{R}=$ skor tertinggi-skor terendah

$$
\begin{aligned}
& =100-65 \\
& =35
\end{aligned}
$$

3. Menentukan Banyak Kelas (BK)

$$
\begin{aligned}
\mathrm{BK} & =1+3,3 \log \mathrm{n} \\
& =1+3,3 \log 32 \\
& =1+3,3(150) \\
& =6,45=6
\end{aligned}
$$

4. Menentukan Panjang Kelas (i)

$$
\mathrm{i}=\frac{R}{B K}=\frac{35}{6}=5,83=6
$$

Tabel 6

Distribusi Frekuensi Kelas Eksperimen

\begin{tabular}{ccccccc}
\hline No & Interval & $\boldsymbol{f}$ & $\mathbf{X i}$ & $(X i)^{2}$ & $\mathbf{f . X i}$ & $\mathbf{f .}(X i)^{2}$ \\
\hline $\mathbf{1}$ & $60-70$ & $\mathbf{1}$ & 67,5 & 4556,25 & 67,5 & 4556,25 \\
2 & $71-76$ & 7 & 73,5 & 5402,25 & 514,5 & 37817,75
\end{tabular}

\begin{tabular}{rcccccr}
3 & $77-82$ & 5 & 79,5 & 6320,25 & 397,5 & 31601,25 \\
4 & $83-88$ & 13 & 85,5 & 7310,25 & 1111,5 & 95033,25 \\
5 & $89-94$ & 5 & 91,5 & 8372,25 & 457,5 & 41861,25 \\
& Jumlah & 32 & & 41467.5 & 2646 & 220374 \\
\hline
\end{tabular}

Batas kelas diperoleh dengan kelas interval bawah dikurangi 0,5 dan kelas atas ditamgah 0,5. Dari kelas interval didapatkan batas interval : 64,5; 70,5; 76,5; 82,$5 ; 88,5 ; 94,5 ; 95,5 ; 100,5$.

Menentukan Rata-rata atau Mean $(\bar{x})$

$$
\bar{X}=\frac{\sum f x i}{n}=\frac{2646}{32}=82,68
$$

Mencari simpangan baku (standar deviasi)

$$
\begin{aligned}
S & =\sqrt{\frac{n \sum f x i-\left(\sum f x i\right)^{2}}{n-(n-1)}} \\
& =\sqrt{\frac{32(220374)-(2646)^{2}}{32 \cdot(32-1)}} \\
& =\sqrt{\frac{7051968-7001316}{992}} \\
& =\sqrt{\frac{50,652}{992}} \\
& =51,06=7,14
\end{aligned}
$$

Nilai Z-Skor

$$
\begin{aligned}
& \mathrm{Z}=\frac{\text { bataskelas-mean }}{\mathrm{s}} \\
& Z_{1}=\frac{64,5-92,68}{7,14}=-1,148 \\
& Z_{2}=\frac{70,5-82,68}{7,14}=-1,705 \\
& Z_{\mathrm{a}}=\frac{76,5-92,68}{7_{3} 14}=-0,865 \\
& Z_{4}=\frac{92,5-92,68}{7,14}=-0,025 \\
& Z_{5}=\frac{88,5-92,68}{7,14}=0,815 \\
& Z_{6}=\frac{94,5-92,68}{7.14}=1,655 \\
& Z_{7}=\frac{100,5-82,68}{7_{1} 14}=2,495
\end{aligned}
$$

Sehingga didapatkan masing-masing Z-Skor

Tabel 7

Mencari Nilai Z-Skor Kelas Kontrol

\begin{tabular}{cccccc}
\hline No & $\begin{array}{c}\text { Batas } \\
\text { Kelas }\end{array}$ & $\begin{array}{c}\text { Mean } \\
\text { (Rata- } \\
\text { rata) }\end{array}$ & $\begin{array}{c}\text { Standar } \\
\text { Deviasi }\end{array}$ & a-b & $\begin{array}{c}\text { Z- } \\
\text { Scor } \\
\text { e }\end{array}$ \\
\hline 1 & 64,5 & 82,68 & 7,14 & $-18,18$ & $-2,54$ \\
2 & 70,5 & 82,68 & 7,14 & $-12,18$ & $-1,70$ \\
3 & 76,5 & 82,68 & 7,14 & $-6,18$ & $-0,86$ \\
4 & 82,5 & 82,68 & 7,14 & $-0,18$ & $-0,02$ \\
5 & 88,5 & 82,68 & 7,14 & 5,82 & 0,81 \\
6 & 94,5 & 82,68 & 7,14 & 11,82 & 1,65 \\
7 & 100,5 & 82,68 & 7,14 & 17,82 & 2,49 \\
\hline
\end{tabular}

sumber data : Data Hasil penelitian diolah

5. Mencari luas Z-Skor dari tabel kurva normal dari O$\mathrm{Z}$ dengan menggunakan angka-angka untuk batas kelas sehingga diperoleh : 0,9445; 0,4555; 0,3051; o,0080; 0,2910; 0,4505; 0,4936

6. Luas kelas interval dengan cara mengurangkan angka-angka O-Z yaitu angka baris pertama dikurangi baris kedua, angka baris kedua dikurangi baris ketiga seterusnya. 


$$
\begin{array}{ll}
15 & 0,9445-0,4555=0,489 \\
16 & 0,4555-0,3051=0,1504 \\
17 & 0,3051-0,0080=0,2971 \\
18 & 0,0080-0,2910=-0,283 \\
19 & 0,2910-0,4505=-0,1595 \\
20 & 0,4505-0,4936=-0,0413
\end{array}
$$

7. Mencari frekuensi yang diharapkan $\left(f_{\varepsilon}\right)$ dengan cara mengalikan luas tiap interval dengan jumlah responden $(n=32)$, sehingga didapat sebagai berikut :

21

$$
220,489 \times 32=15,648
$$

$230,1504 \times 32=4,8128$

$240,2971 \times 32=9,5072$

$250,283 \times 32=-9,056$

$260,1595 \times 32=-5,104$

$270,0413 \times 32=-1,3792$

$$
\text { Dengan menggunakan }
$$

Rumus

$x^{2}=\sum_{i=1}^{k} \frac{(f o-f e)^{2}}{f e}$ dari tabel nilai $\chi^{2}$ hitung diperoleh

- 60,981, sedangkan $\chi^{2}$ tabel pada taraf kesalahan $5 \%$ dengan $\mathrm{dk}=\mathrm{k}-1=6-1=5$ yaitu 11,07, Jika $\chi^{2}$ hitung $>\chi^{2}$ tabel, maka data tidak terdistribusi normal, sedangkan jika $\chi^{2}$ hitung $<\chi^{2}$ tabel, makadata terdistribusi normal. Dari hasil perhitungan ternyata $\chi^{2}$ hitung $<\chi^{2}$ table yaitu $-60,981<11,07$. Ini berarti data terdistribusi normal.

\section{b. Uji Homogenitas}

Tabel 8

Uji Homogenitas Kelas Eksperimen dan Kelas Kontrol

\begin{tabular}{ccc}
\hline No & $\begin{array}{c}\text { Kelas } \\
\text { Eksperimen } \\
\mathbf{x}_{1}\end{array}$ & $\begin{array}{c}\text { Kelas Kontrol } \\
\mathbf{x}_{2}\end{array}$ \\
\hline 1 & 85 & 70 \\
2 & 75 & 65 \\
3 & 85 & 65 \\
4 & 75 & 75 \\
5 & 85 & 65 \\
6 & 80 & 70 \\
7 & 85 & 70 \\
8 & 100 & 65 \\
9 & 65 & 65 \\
10 & 80 & 70 \\
11 & 75 & 80 \\
12 & 90 & 65 \\
13 & 85 & 80 \\
14 & 90 & 75 \\
15 & 90 & 95 \\
16 & 75 & 60 \\
17 & 80 & 80 \\
18 & 85 & 80 \\
19 & 75 & 65 \\
20 & 90 & 75 \\
21 & 85 & 75 \\
22 & 85 & 70 \\
23 & 85 & 70 \\
24 & 80 & 70 \\
25 & 85 & 75 \\
26 & 85 & 70 \\
27 & 75 & 60 \\
28 & 85 & 85
\end{tabular}

$\begin{array}{ccc}29 & 80 & 65 \\ 30 & 90 & 60 \\ 31 & 85 & 70 \\ 32 & 75 & 60 \\ \text { Jumlah } & 2645 & 2135 \\ \text { Rata-rata } & 82,65 & 71,16 \\ \text { Max } & 100 & 95 \\ \text { Min } & 65 & 60 \\ \text { S } & 7,14 & 8,06 \\ \mathbf{s}^{\mathbb{2}} & 50,979 & 64.963 \\ \mathbf{F} & 1,27 & \\ \text { dk } & 32 & \\ \text { (pembilang) } & & \\ \text { dk } & 32 & \\ \text { (penyebut) } & & \end{array}$

Sesuai dengan tabel diatas maka dapat diperoleh nilai varians terbesar danterkecil yaitu :

1. varians terkecil berada di kelas eksperimen $\left(\$^{2}=50,979\right)$

2. $\quad$ varians terbesar berada di kelas kontrol $\mathrm{S}^{2}=64,963$

a. Mencari $F_{\text {hitung }}$

Sesuai dengan perhitungan diperoleh varians terbesar $=64,963$ dan varians terkecil $=50,979$, maka dimasukkan kedalam rumus berikut :

$$
\begin{aligned}
\mathrm{F} & =\frac{\text { Variansterbesuy }}{\text { Variansterkecil }} \\
& =\frac{64,962}{50,979}=1,27
\end{aligned}
$$

b. Mencari $F_{\text {tabel }}$

- $\quad$ dk pembilang $=32-1=31$

- dk penyebut $=32-1=31$

- taraf signifikan $5 \%$, sehingga diperoleh $F_{\text {tabel }}=$ 2,38

c. Kesimpulan

Harga $F_{\text {hitung }}$ selanjutnya di bandingkan dengan harga $F_{\text {tabel }}$ dengan $\mathrm{dk}$ pembilang $\mathrm{dk}(32-1=31) \mathrm{dan} \mathrm{dk}$ penyebut $(32-1=31)$. Berdasarkan dk tersebut dan untuk taraf kesalahan 5\%, maka harga $F_{\text {tab }=x}=2,38$. Jadi, harga $F_{\text {hitung }}<\mathrm{F}_{\text {tabel }}(1,27<2.38)$. Dengan demikian dapat dinyatakan bahwa varians kedua kelompok sampel yang digunakan dalam penelitian ini adalah homogen.

\section{c. Uji Hipotesis}

Uji hipotesis dilakukan untuk mengetahui apakah ada perbedaan antara hasil belajar siswa setelah menggunakan model pembelajaran probing-promting dan sebelum menggunakan model pembelajaran probing-prompting yaitu dengan menggunakan model pembelajaran jigsaw pada mata pelajaran PPKn kelas VII SMP Negeri 1 Sape. Berdasarkan hasil penelitian diperoleh data pada tabel 8 .

Sebelum menguji dua variabel yang saling berpengaruh, maka terlebih dahulu melakukan analisis tentang pengaruh antara kedua sampel dengan menggunakan korelasi product moment, yaitu: 


$$
\begin{aligned}
& r_{x y}=\frac{F^{x y}}{\sqrt{\left.E^{2} x^{2}\right) E^{2} y^{2}}} \\
& =\frac{229,043}{\sqrt{(1.446,204)(810,71)}} \\
& =\frac{2299_{2} 043}{\sqrt{1.172,452,044}} \\
& =\frac{229.043}{1.082 .798}=0.2115
\end{aligned}
$$

Uji hipotesis untuk menentukan pengaruh antara hasil belajar PPKn pada siswa kelas eksperimen dan kelas kontrol dilakukan uji-t dengan rumus polled varians:

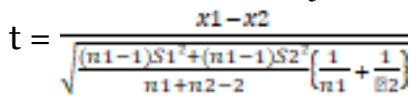

Diketahui:

$X_{1}=82,65$

$X_{2}=71,16$

$n_{1}=32$

$n_{2}=32$

$S_{1}{ }^{2}=50,979$

$S_{2}{ }^{2}=64,963$

$t=\frac{82,65-71,16}{\sqrt{\frac{(32-1) 50,979+(32-1) 64,963}{32+32-2}\left\{\frac{1}{32}+\frac{1}{32}\right\}}}$

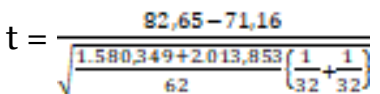

$\mathrm{t}=\frac{11,49}{\sqrt{\frac{\sqrt{5384202}}{622}\left(\frac{2}{32}\right)}}$

$\mathrm{t}=\frac{11,49}{\sqrt{57,971,0,0625}}$

$\mathrm{t}=\frac{11,49}{\sqrt{1,623}}$

$\mathrm{t}=\frac{11,49}{1,903}=6,037$

Setelah dihitung dengan dilakukan uji hipotesis dengan menggunakan uji-t untuk menjawab rumusan masalah dan untuk mengetahui apakah hipotesis yang menjawab apakah hipotesis yang diajukan diterima atau ditolak. Berdasarkan hasil penelitian analisis uji-t, maka nilai $t_{\text {hitung }}$ tersebut dibandingkan dengan $t_{\text {tabel }}$, dimana $t_{\text {hitung }}=6,037$ dan $t_{\text {tabel }}$ dengan $\mathrm{dk}=n_{1}+n_{2}-2=32+$ $32-2=62$. Dengan dk 62 pada taraf signifikan $5 \%$, maka $t_{\text {tabel }}=1,669$. Dari perhitungan diperoleh $t_{\text {hi }}$ rung $<t_{\text {tabel }}$ maka Ha diterima dan Ho ditolak. Sebaliknya jika $t_{\text {hitung }}>t_{\text {tabel }}$ maka Ho ditolak Ha diterima. Dari perhitungan diperoleh $t_{\text {hitung }}>t_{\text {tabel }}$, ini berarti bahwa hipotesis alternatif (Ha) yang berbunyi "ada pengaruh model pembelajaran probing-prompting terhadap hasil belajar PPKn kelas VII SMP Negeri 1 Sape Tahun Pelajaran 2017-2018.

Uraian di atas, maka terdapat pengaruh yang signifikan antara siswa yang diajarkan dengan menggunakan model pembelajaran probing-prompting dibandingkan dengan mengunakan model pembelajaran konvensional. Hal ini berarti bahwa hasil belajar PPkn siswa yang menggunakan model pembelajaran probingprompting lebih baik dari pada hasil belajar PPkn yang menggunakan model pembelajaran konvensional. Hal ini dikarenakan pada materi yang diajarkan siswa saling bertukar pengetahuan antara siswa yang satu dengan yang lainnya dapat belajar lebih efektif dan efesien, sehingga dapat ditarik kesimpulan dari hasil belajar. Sedangkan pada pembelajaran tanpa menggunakan model pembelajaran probing-prompting, dan hanya menggunakan pembelajaran dengan model konvensional yang hanya menekankan pada guru yang lebih aktif, siswa hanya membaca, menulis, mendengar dan mengacu pada buku pegangannya.

\section{TEMUAN DAN DISKUSI}

Secara umum, hasil penelitian ini telah membuktikan hipotesis yang diajukan, yaitu terdapat pengaruh yang signifikan hasil belajar PPKn siswa antara siswa yang belajar dengan menggunakan model pembelajaran probing-prompting dan siswa yang menggunakan model pembelajaran konvensioanal. Sebelum melakukan uji hipotesis terlebih dahulu melakukan uji analisis data yaitu terlebih dahulu melakukan uji normalitas data hasil belajar kelas eksperimen dilakukan dengan cara membandingkan hasil $\chi^{2}$ hitung dengan $\chi^{2}$ table pada taraf signifikan 5\%.

Dengan demikian dari hasil $\chi^{2}$ hitung $=-60,981$ sedangkan pada taraf signifikan $5 \%$ dan $\mathrm{dk}=$ jumlah kelas $-1=6-1=5$ didapatkan harga $\chi^{2}$ tabel $=11,07$ jadi perhitungan diatas dapat dikatakan $\chi^{2}$ hitung $<\chi^{2}$ table. Maka distribusi data kelas eksperimen dapat dinyatakan terdistribusi normal. Sedangkan kelas kontrol hasil $\chi^{2}$ hitung $=5,306$ sedangkan pada taraf signifikan 5\% dan $\mathrm{dk}=$ jumlah kelas $-1=6-1=5$ didapat harga $\chi^{2}$ tabel $=$ 11,07 jadi perhitungan diatas dapat dikatakan $\chi^{2}$ hitung $<\chi^{2}$ table. Maka distribusi data kelas kontrol dapat dinyatakan terdistribusi normal. Dengan demikian kedua kelas dapat dinyatakan terdistribusi normal.

Untuk uji homogenitas berdasarkan hasil perhitungan uji homogenitas pada kedua kelas diperoleh bahwa nilai kelas eksperimen dan kelas kontrol dapat dikatakan homogen jika nilai $F_{\text {hitung }}$ lebih kecil dari nilai $F_{\text {tabel }}$ ( $F_{\text {hitung }}<F_{\text {tabel }}$ ) pada taraf signifikan 5\% dari data yang diperoleh nilai $F_{\text {hitung }}=1,27$ dan nilai $F_{\text {tabel }}=2,38$. Jadi $F_{\text {hit } \text { \& ng }} 1,27<F_{\text {tabel }} 2,38$ berdasarkan kriteria yang ada, jika $F_{\text {hitung }}<F_{\text {tabel }}$ maka kedua kelas dapat dikatakan memiliki varians yang sama, yang menandakan kedua kelas homogen pada taraf signifikan $5 \%$.

Sesuai hasil penelitian yang diperoleh dari analisis data dan pengujian hipotesis yang telah menunjukkan bahwa "ada pengaruh model pembelajaran proning- 
prompting terhadap hasil belajar PPkn siswa kelas VII SMP Negeri 1 Sape Tahun Pelajaran 2017-2018. Perbedaan yang signifikan ini terlihat dari analisis uji hipotesis yang telah dilakukan dengan menggunakan ujit. Hasil analisis menunjukkan bahwa $t_{\text {hitung }}$ sebesar 6,037 lebih besar dari $t_{\text {tabel }}$ dengan taraf signifikan $5 \%$ dan dk 62 yaitu 1,669. Berdasarkan kriteria pengujian, yaitu tolak Ho jika $t_{\text {hitung }}<t_{\text {tabel }}$, maka hipotesis (Ho) yang diajukan dalam penelitian ini ditolak dan hipotesis (Ha) diterima. Ha inilah yang menyatakan bahwa terdapat perbedaan yang signifikan antara siswa yang mengikuti pembelajaran dengan model pembelajaran probing-prompting dan siswa yang menggunakan model pembelajaran konvensional.

Adanya pengaruh yang signifikan menunjukkan bahwa penerapan model pembelajaran probingprompting berpengaruh terhadap hasil belajar PPKn siswa. Untuk mengetahui besarnya pengaruh antara model pembelajaran probing-prompting dan model pembelajaran konvensional, dapat dilihat dari rata-rata skor hasil belajar PPKn siswa antara kedua kelompok. Rata-rata hasil belajar PPKn siswa kelas eksperimen adalah 82,65, sedangkan rata-rata hasil belajar PPKn siswa kelas kontrol adalah 71,16 . Hal ini berarti, rata-rata skor kelas eksperimen lebih besar dari rata-rata skor kelas kontrol. Dengan demikian, dapat disimpulkan bahwa pembelajaran menggunakan model pembelajaran probing-prompting lebih berpengaruh baik terhadap hasil belajar PPKn pada siswa kelas VII di SMP Negeri 1 Sape dibandingkan dengan pembelajaran dengan menggunakan model pembelajaran konvensioanal.

Penjelasan tersebut menunjukkan bahwa memang terdapat pengaruh yang signifikan hasil belajar PPKn antara siswa yang menggunakan model pembelajaran probing-prompting dengan model pembelajaran konvensioanal.

Model pembelajaran probing-prompting memberikan kebebasan untuk mengambil inisiatif terhadap pembelajaran yang diinginkan. Hal ini dikarenakan pada model pembelajaran probing-prompting siswa dilibatkan secara penuh dalam pembelajaran dan melatih sikap kesiapan siswa, meningkatkan kesopanan dan memberikan pengetahuan yang luas. Penigkatan dapat terjadi karena beberapa hal. Pertama, pembelajaran yang menerapkan model pembelajaran probing-prompting dapat mengubah pembelajaran yang awalnya berpusat pada guru menjadi pembelajaran yang berpusat pada siswa. Siswa menjadi lebih termotivasi dan aktif dalam mengikuti pembelajaran. Dalam penerapan model pembelajaran probing-prompting, siswa disuruhmengembangkan keberanian dan keterampilan dalam menjawab dan mengemukakan pendapat. Mereka aktif dalam menyampaikan maupun menjawab dan mengemukakan pendapat. Mereka aktif dalam menyampaikan maupun menjawab pertanyaan dari guru dan teman-temannya. Apabila siswa aktif dalam kegiatan pembelajaran maka berdampak pada meningkatnya motivasi belajar siswa, sehingga hasil belajar siswa pun dapat meningkat.

Model pembelajaran ini diterapkan pada pembelajaran untuk mencapai kompetensi yang sudah ditetapkan dan diketahui siswa dengan membagikan bahan belajar yang lengkap. Suherman (2008:6) yang menyatakan bahwa, teknik Probing-Prompting adalah pembelajaran dengan cara guru menyajikan serangkaian petanyaan yang sifatnya menuntun dan menggali sehingga terjadi proses berpikir yang mengaitkan pengetahuan siswa dan pengalamannya dengan pengetahuan baru yang sedang dipelajari. Peranan teknik ini adalah menjadi jalan alternatif untuk mempermudah siswa melakukan akomodasi dan membangun pengetahuan sendiri.

Berbeda dengan model pembelejaran konvensioanal yang dimana siswa hanya membaca, menulis, dan mendengarkan. Sehingga kegiatan belajar siswa hanya terpacu pada mebaca, menulis, dan mendengarkan saja. Kegiatan proses belajar mengajar lebih berpusat pada guru dan pada buku pegangan siswa sehingga komunikasi satu arah dari guru kepada siswa kurang. sedang siswa hanya membaca, menulis, dan mendengarkan apa yang disampaikan guru sehingga cenderung meminimalkan keterlibatan siswa serta guru nampak lebih aktif atau dan belum menerapkan model pembelajaran yang inovatif.

Paparan tersebut menjadi alasan pendukung bahwa model pembelajaran probing-prompting, memang logis lebih berpengaruh baik terhadap hasil belajar dibandingkan dengan model pembelajaran konvensioanal yang hanya menstransfer pengetahuan tanpa memperhatikan potensi siswa.

\section{E. SIMPULAN DAN SARAN}

Berdasarkan hasil penelitian dan pembahasan yang telah diungkapkan pada bagian sebelumnya, maka dapat diambil kesimpulan bahwa terdapat pengaruh yang signifikan hasil belajar PPKn siswa kelas eksperimen dengan menggunakan model pembelajaran probingprompting dengan kelas kontrol yang menggunakan model pembelajaran konvensioanal pada siswa kelas VII di SMP Negeri 1 Sape Tahun Pelajaran 2017-2018. Hal ini bisa dilihat dari nilai rata-rata kelas eksperimen 82,65 dan nilai rata-rata kelas kontrol 71,16. Berdasarkan hasil perhitungan uji hipotesis dengan menggunkan rumus uji-tes, maka diperoleh $t_{\text {hitung }}$ sebesar 6,037 sedangkan nilai $t_{\text {ta }}$ ell pada taraf signifikan $5 \%$ dengan $\mathrm{dk}=n_{1}+n_{2}-2=32+32-2=$ 62 diperoleh harga $t_{\text {tabel }}$ sebesar 1,669. Jadi dari hasil perhitungan dapat disimpulkan $t_{\text {hitung }}>t_{\text {tabel }}$.

Dengan demikian, disarankan bagi sekolah untuk menerapkan model pembelajaran probing-prompting ini pada mata pelajaran PPKn karena mampu 
meningkatkan prestasi siswa. Bagi guru untuk bervariasi dalam mengajar dan bagi peneliti berikutnya untuk melakukan kajian penelitian pada variable lainnya.

\section{UCAPAN TERIMA KASIH}

Penulis mengucapkan terima kasih kepada pihak Universitas Muhammadiyah Mataram yang senantiasa memberikan saran, masukan, dan dana kepada penulis sehingga artikel ilmiah ini selesai dengan tepat waktu.

\section{DAFTAR RUJUKAN}

[1] Z. Muttaqin and M. Rais, "Menelusuri Pendidikan Kecakapan Hidup (Life Skill) Pada Mata Pelajaran PPKn Siswa Kelas IV di SDN 1 Terong Tawah Kec. Labuapi Kabupaten Lombok Barat Tahun Pelajaran 2014/2015," Civ. Pendidikan-Penelitian-Pengabdian Pendidik. Pancasila dan Kewarganegaraan, vol. 4, no. 2, pp. 87-94, 2018.

[2] H. A. Kamaluddin and I. Harianti, "Model Pembelajaran Assurance, Relevance, Interest, Assessment, Satisfaction dan Hasil Belajar Siswa Kelas VII Pada Mata Pelajaran PPKn di Vii di MTs Negeri 1 Mataram Tahun Pelajaran 2015/2016," Civ. Pendidikan-PenelitianPengabdian Pendidik. Pancasila dan Kewarganegaraan, vol. 4, no. 1, pp. 51-62, 2016.

[3] A. Sakban and K. Aini, "Penerapan Model Pembelajaran Concept Mapping Untuk Meningkatkan Motivasi dan Prestasi Belajar PKn Pada Siswa Kelas V MI NW Apitaik Lombok Timur Tahun Pelajaran 2015/2016," Civ. Pendidikan-Penelitian-Pengabdian Pendidik. Pancasila dan Kewarganegaraan, vol. 4, no. 1, pp. 123-128, 2016.

[4] K. Sundara and M. Basri, "Penerapan Metode Problem Based Instruction (PBI) untuk Meningkatkan Hasil Belajar Ppkn Siswa Kelas IV di SDN Galang Bulan Desa Jelantik Kecamatan Jonggat Kabupaten Lombok Tengah Tahun Pelajaran 2011-2012," Civ. PendidikanPenelitian-Pengabdian Pendidik. Pancasila dan Kewarganegaraan, vol. 4, no. 2, pp. 51-58, 2018.

[5] H. Miftahul, "Model-model Pengajaran dan Pembelajaran," Yogyakara: Pustaka Pelajar, 2013.

[6] P. D. Sugiyono, "Metode Penelitian dan Pengembangan," Res. Dev. D, 2015.

[7] J. W. Creswell and J. D. Creswell, Research Design: Qualitative, Quantitative, and Mixed Methods Approaches. Sage publications, 2017.

[8] W. Sanjaya, Perencanaan dan desain sistem pembelajaran. Kencana, 2015.

[9] P. Sugiyono, "Dr. 2010," Metod. Penelit. Kuantitatif, Kualitatif, dan R\&D. Bandung CV Alf.

[10] M. Anshori and S. Iswati, "Metodologi penelitian kuantitatif," Surabaya Pus. Pnb. dan Percetakan UNAIR, 2009.

[11] P. Sugiyono, Metode Penelitian Kuantitatif, Kualitatif, dan R\&D. 2013.

[12] H. Darmadi, "Metode penelitian pendidikan." Bandung: Alfabeta, 2011.
[13] S. Arikunto, Prosedur Penelitian Suatu Pendekatan Praktik. 2006.

[14] S. Nasution, Berbagai pendekatan dalam proses belajar dan mengajar. PT. Bina Aksara, 2000.

[15] R. Kuncoro, Engkos Achmad, Cara Menggunakan dan Memaknai Path Analysis (Analisis Jalur). Bandung, 2013.

[16] A. Sugiyono, "Pengantar Statistik Pendidikan," Jakarta Graf. Persada, 2004. 